\title{
Does Institutional Quality Influence the Oil price- economic Growth Nexus: Evidence from African Oil Exporting Economies
}

\author{
Lucky Tuzuka Musikavanhu, Jonah B. Tlhalefang, Mogale Ntsosa, and Malebogo Bakwena
}

\section{ABSTRACT}

The primary contribution of this study is to investigate how institutional quality affects the relationship between the oil price changes and economic growth on net oil exporters in African countries split into net oil exporters and net oil importers. Whether oil price changes are good for the growth patterns of African economies lies on the interaction between oil prices and institutional quality. Oil price increases for oil exporting economies result in increased revenue which will be distributed to economic boosters of the economy however, the net effect of such revenues to the economies solely depends on how institutions distribute the oil rents to the various sectors of the economy. In contrast to the traditional direct effect of oil price changes to economic growth, this study shows that the impact of oil price on economic growth is non-monotonic in institutional quality. Oil exporting economies can benefit from oil price increase if they have good institutions. This has been assessed by including an interaction term, oil price-institutional quality, in the Panel Auto-Regressive (PARDL) using the Pooled Mean Group (PMG) model. Such a methodological framework has an added advantage over other model as it allows for modelling of data with different orders of integration. The PMG estimator allows the intercepts, short-run coefficient, and the error variance to differ freely across groups while the long-run coefficients are the same. Using data from 1990 to 2016, it is revealed that the sign of the coefficient interaction is positive and significant as theoretically expected. Furthermore, the coefficient of the interaction term is greater than the coefficient of oil price as anticipated. This would mean that as long as institutional quality is good enough, oil price changes positively influence economic performance on oil exporting economies. As such, the findings of this thesis have important policy implications. Since implementation of quality institutions is an on-going process, the study results suggest that institutions should be strengthened towards economic activities rather than for political mileage.

Keywords: economic growth, institutional quality, net oil exporters, oil price.
Submitted : August 16, 2021

Published : September 10, 2021

ISSN: 2507-1076

DOI: $10.24018 /$ ejbmr.2021.6.5.1058

Lucky Tuzuka Musikavanhu (e-mail:

lucky.musikavanhu@baisago.ac.bw)

ltmusikavanhu63@gmai.com)

Jonah B. Tlhalefang

(e-mail: TLHALEFJ@ub.ac.bw)

Mogale Ntsosa

(e-mail: ntsosamm@ ${ }^{@}$ ub.ac.bw)

Malebogo Bakwena

(e-mail: thokweng ${ }^{\circledR}$ ub.ac.bw)

*Corresponding Author

\section{INTRODUCTION}

The objective of the paper is to investigate the impact of oil price and institutional quality on economic growth of African economies. The theoretical and empirical analysis between oil price and economic growth has continued to receive considerable attention at global scale. However, the influence of institutional quality has been undermined in recent studies. The relevance of African economies is on the presence of net oil exporters and net oil importers. Over the years, the global usage of oil has been increasing [1]. The rising industrial growth, residential development and rising food production also contributed to increasingly high demand of oil in net oil importers [2]. Lately, oil is the most crucial input of production and products from oil are extensively used in transportation, power generation, as well as manufacturing and in other service sectors which contribute significantly to economic growth. As such, the oil price index is one of the most important indices in the global economy; hence it is used as a reference price for related energy resources [3]. Economies for net oil exporters largely depend on oil revenues generated from oil resources. The amount of revenues is largely determined by the international price of oil. Similarly, the demand of oil and extraction of oil is largely influenced by changes in global oil prices the global.

Furthermore, the diverse institutional qualities which range from poor to strong among African economies have necessitated the study. Globally, the quality of institutions for Africa has been ranked poorly compared to other regions [4]. For instance, institutions have been realized to be highly corrupt and overridden by the political spectrum within the region compared to European and American institutions which operate independently. Furthermore, African institutions face sustainability crisis with small staff and budgets due to insufficient and irregular funding thus creating institutional fragility and acute sustainability within the region [4]. The institutions, both at country and regional level 
are relatively small in scope and influence, limited in their geographical reach and dependent on external support and funding. Furthermore, African institutions redistribute activities at the expense of production activities, create monopolies instead of competitive conditions and restrict opportunities thus resembling Western institutions which lack a true representation of the socio economic and cultural realities of African states [5]. Resultantly, such institutional weaknesses create leakages within the region with an estimated annual loss of USD 90 billion [6]. Epaphra and Kombe [7] concluded that the growth patterns of African economies are likely to be affected by institutional characteristics like political and civil rights, government effectiveness and independence of the judicial system hence need for them to be improved.

The paper has employed Panel Auto-regressive Distributed Lag (PARDL) since it has an added advantage of modeling data regardless of the order of integration. The I -(0) and I(1) on the variables have influenced the use of the panel autoregressive distributive lag (PARDL) model in this research. This approach improves on the ones employed in previous studies in that it increases the efficiency in analysis while capturing both coexistent and temporal relationships among variables [8]. Furthermore, the PARDL allows investigating both the short-run and long-run effect changes in oil price on economic growth of the global sample and different oil groups.

Following is the review of factors which has influenced the global oil prices over the past three decades. Section three presents some facts of both oil importers and oil exporters. The related empirical evidence is presented in section four. The estimation techniques and major findings and policy implications are discussed in section five and six, respectively while section seven concludes.

\section{OIL PRICE CHANGES}

The change in oil prices has been affected by a plethora of factors since 1970. Notably, geopolitical events and other events which have disrupted the demand and supply have been the main drivers of global oil price changes for the past five decades [9]. Increases in crude oil prices prior to 1990 have been largely determined by Arab oil embargo, Iranian revolution, Iran Iraq war and the decision by Saudi Arabia to abandon the swing producer role [9]. The slight fluctuations in crude oil price between 1990 and 1999 were caused by the Asian crisis and the decision to allow Iraq to increase its oil exploration. Furthermore, global decline in oil production in major oil producers together with increased global oil demand contributed to an increase in crude oil price from 1999 to 2012 [10]. The general upward trend in oil price over the same period suffers a setback in 2008 as the world plunged into financial recession which left most industries scaling down their operations. However, the price bounced back in 2010 as countries were pulling themselves out from the effects of the financial crisis. The decision by OPEC countries to increase oil production triggered a downward pressure on the crude oil price from 2012. Currently, the Asian crisis and the global pandemic of COVID-19 is triggering a downward pressure on the price of crude oil price
[11].

Despite the demand and supply which were ignited by geopolitical and other events, the price of crude oil has been affected by other factors. For instance, the financial markets played aa significant role in influencing the price of crude oil [12]. The participation in the trading of futures market of oil and other energy derivatives has discovered the prices of such commodities. The motive of the market participants in future contracts of oil commodity has an effect on the price of crude oil. Consumers may purchase future in order to avoid the possibility of a rise oil price above a certain level while on the other hand the oil producers may sell the oil future contract so as to lock the price of oil in the future period. Furthermore, non- direct oil participants add and reduce liquidity of futures contracts so as to profiteer from oil price movements by reducing and amplifying the movement of oil prices [12]. The trading in futures contracts of oil has been increasing since 1990 for both commercial and non-commercial investors hence increasingly influencing the price of crude oil [9].

The correlations between crude oil price and other commodities like silver, wheat etc. before and after the global economic periods influenced investors to invest into index funds and exchange traded funds. These investments greatly influenced the price of crude oil especially after 2009 where a high positive correlation was observed between crude oil price and other commodities like wheat, silver, and soya beans [9]. Furthermore, a positive correlation between crude oil price and the major U.S stock index, S\&P 500 was realized since 2007 . The stock index movements strongly affected the movements in crude oil prices since they were having similar, they were having similar risk return characteristics.

The crude oil price is pegged in USD hence the changes in value of the USD relative to other currencies impact the crude oil price. A depreciation of the USD reduces the effective price of oil outside US thus stimulating increased demand of US oil thus putting an upward pressure on the price of crude oil. The profits for non-US producers will be reduced following a depreciation of USD hence a counter movement of targeting higher oil prices is implemented so as to maintain real budget levels and purchasing power in the world markets. Furthermore, the depreciation of the USD has the effect of reducing the dollar denominated assets which are measured in foreign currency. Resultantly, foreign investments in commodities like oil increases as investors hedge against inflation thus causing the price of crude oil to increase [9].

The need to balance between supply and demand by keeping or drawing down inventories of crude oil has a bearing on the price of crude oil. Oil inventories are kept when oil supply outstrips oil demand as was realized during the end of 2008 and beginning of 2009 where United States of America (USA) and other OECD countries registered huge inventories amid a decline in oil demand necessitated by the global financial recession [9]. Contrastingly, the inventories of crude oil will be drawn when oil consumption surpasses oil production. Consequently, current, and future demand of oil is fulfilled by oil inventories hence the level of such inventories has an influence over the spot and future price of oil. The price for the future contracts is expected to increase if the market speculates a future increase in oil demand or lower supply thus encouraging oil inventories build up so that they can be sold at a higher expected price. On the other hand, 
spot prices tend to increase relative to future prices amid expectations of a decline of a loss in oil production or a rise in future consumption.

\section{INSTITUTIONAL FRAMEWORK}

African countries possess different institutions varying from weak to strong institutions. For instance, Botswana has low levels of corruption, no resource curse good governance and rule of law while the opposite is true for Kenya [13]. The abysmal results from the performance of the Nigerian economy have been tainted to institutionalized corruption which impeded public office holders from improving the economy despite the plenty of human and natural resources at their disposal [14]. Uganda, Zambia Cameroon, Chad authorities jeopardized the strength of institutions through their practice of unrestrained corruption and political maneuvering [14]. On the other side, Mauritius, South Africa, Cape Verde, and Namibia have good institutional quality scores comprising of rule of law, good governance and informal institutions playing an influential role in country wide decision making. For instance, freedom of media, civil society participation and pressure groups which tracked public sector decisions exists in South Africa. Similarly, the decentralization of decision-making processes in Namibia since 1990 contributed immensely to the reduction of corrupt activities and improvement in accountability [15]. Furthermore, the judiciary system of Namibia was independent hence reducing interference from other arms of the government which may reduce the quality of institutions. Following this, it will be interesting to analyze the role that quality of institutions plays in influencing economic performance of African oil exporting economies in the wake of oil price change.

\section{STYLIZED FACTS}

\section{A. Oil Production in Oil Exporting Economies}

Over the past three decades, the production levels of oil have been fluctuating between the levels of 4 million barrels per day to 9.2 million barrels per day. The changes in production levels emanated from both OPEC and Non- OPEC countries and were mainly driven by the change in oil prices as well as the institutional framework existing in various African economies [16]. Fig. 1 below shows the trend in oil production in Africa from 1980 to 2015.

Fig. 1 indicates that oil production increased from 1982 to 1986 due to the high prices of oil which averaged US\$ 27 per barrel. The return of oil fields of Rudeis and Ra'sudry in 1975 and the final surrender in 1982 in Egypt boosted production to an average of 720 thousand b/d over thus adding to the stock of production in Africa by a significant proportion. Fig. 1 is showing a drop in oil production levels by approximately $20.79 \%$ from 6.01 million barrels a day to 4.8 million barrels a day from 1986 to 1987 as oil prices tumbled.

Fig. 1 is showing a gradual increase in oil production among African economies from 1990 to 1999. The annual growth was estimated to be $10 \%$ and in 2000 Africa's production was estimated to be 6.7 million barrels a day. The gradual increase in oil price over the same period has been the major driver of such improved production level as more investments were made in the region. For instance, OPEC members Nigeria and Libya were producing more than a million b/d in the 1980s and 1990s while the increase in production in Libya in the 1990s was driven by deep water drilling and discovery of deep-water fields. There was an oil bust in Nigeria during the 1990s. 159 oil fields and 1481 well were in operation during the same period. Moreover, Nigeria was also producing sweet oil which was in high demand but decreased slightly during the 1990 s due to the civil unrest which hindered oil production. The end of military rule in 1999 which was replaced by civilian rule brought confidence in the market which attracted more foreign investors in the oil sector Furthermore, new discoveries of oil fields in the NonOPEC representatives of Equatorial Guinea and Sudan in 1993 and 1994 contributed to an improvement in output by approximately 400 thousand barrels per day, respectively.

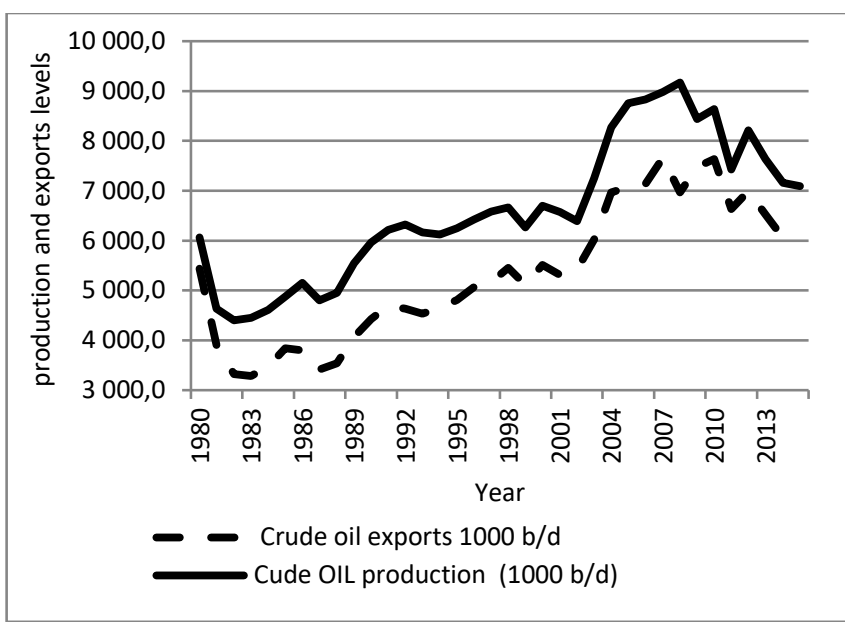

Fig. 1. Crude oil exports relative to production in Africa. Source: [17].

A decrease in oil production from 2000 to 2002 is also indicated in Fig. 1. The decrease of oil production over a twoyear period from 2000 was accelerated by political crisis together with deep rooted corruption in Angola Nigeria and Congo which disturbed oil exploration activities despite the positive gains in oil prices over the same. Furthermore, the drying up of some oil wells in Congo contributed to a decline in oil output over the same period [18].

Oil production recorded a steep rise from 2002 reaching a record level of 9.171 million barrels per day in 2008, representing an estimated $47 \%$ increase in production levels. During the same six-year period from 2002 to 2008, there were more exploration as the price of oil jumped by more than. For instance, Lasmo, an oil extracting investor discovered large oil reserves in the south of Tripoli. The discovery of deposit in 2005 by Repso YPF and the removal of sanctions in 2006 which cleared US oil companies to explore oil production. Production in Angola started to increase from 2004 as new oil fields were discovered and increased demand from China and USA which made Angola the exporter of crude oil to these markets. The increase in production made Angola to be admitted in the OPEC group in 2007 and increased is output by an estimated $85 \%$ to a record level of 1.894 million b/d in 2008 which was contributed by the developments of deep-water offshore fields in the Block zero [19]. 
Oil exporting countries have been playing an increasing role as global investors since most of the oil revenues were used as investment funds globally. These oil exports generate revenues that translate into economic activity and income of countries [20], [21]. The more the oil produced in Africa the more oil will be exported hence the pattern for oil production has been the same as the pattern of oil exports in Africa as shown in Fig. 1.

Fig. 1 shows a decline by $39.65 \%$ of Oil exports in Africa from 1980 to 1983 was followed by a slight increase of $15.7 \%$ to 3.8 million b/d by 1986 . The 1986 oil crisis attributed to the $10 \%$ decrease in oil production in the region in 1987. From 1987 the oil exports recovered for the following two decades reaching a peak level of an estimated 7.6 million b/d in 2010. The rise in global oil prices, increase discovery of new oil fields in OPEC and Non-OPEC countries contributed to such a rise in crude oil exports. Tumbling of oil prices resulted in decrease of oil exports from 6.9 million b/d to 6.2 million b/d by 2015. Below is a graph showing trend of crude oil exports in Africa relative to its production.

\section{B. Economic Growth}

Overall improvement in in the performance of African region has been witnessed for the two decades dating back to 1990. The drought which hit Africa in the early 90s resulted in $0 \%$ average growth rate in 1992 [22]. However, the African economy improved at an average annual growth rate of $3 \%$ over the 1993 to 2003 as more resources were extracted and increased inflow of foreign direct investment which was largely influenced by improvement in the quality of institutions among various African economies [22]. The improvement in economic outlook of Africa to an annual average of $5.2 \%$ from 2003 to 2006 was largely contributed by the structural change from the traditional agriculture to manufacturing, construction as well as services which played a substantial role in productivity catch up [23].

Fig. 2 shows a decline in economic growth from an average of $7 \%$ in 2006 to $1.8 \%$ in 2010 as most economies plunged into global financial recession. Global economies responded to 2008 economic meltdown by adopting various economic policies. For instance, USA reduced its interest rates and increased money supply into the financial system [22]. Consequently, regional economies improved with Africa improving by $5 \%$ in 2013. From 2013 the African Growth rate improved by $3 \%$ as depicted in Fig. 3. Hamilton [24] concluded that such changes in economic performance were also attributed by global oil price changes. Globally, Africa has been regarding as the least developed region.

Table I reveals that real GDP for oil exporting countries expanded more strongly than the oil importing countries with Equatorial Guinea recording the highest growth within the last decade in Africa. Despite weak institutional framework in Equatorial Guinea, the increased foreign investments in the oil sector were the major reason behind a positive growth in recent years. The growth pattern was further improved by the inflow of foreign aid from the donor community which was channeled to productive sectors of the economy [25]. The sluggish economic growth of Libya was largely contributed by Libyan conflict [26]. Although the performance for oil importing economies has been generally lower than oil exporting economies, countries like Ethiopia, Mozambique,
Rwanda, Ghana, Tanzania, Zambia, and Uganda recorded a positive economic growth of at least $6 \%$ on an annual basis as indicated in Table I.

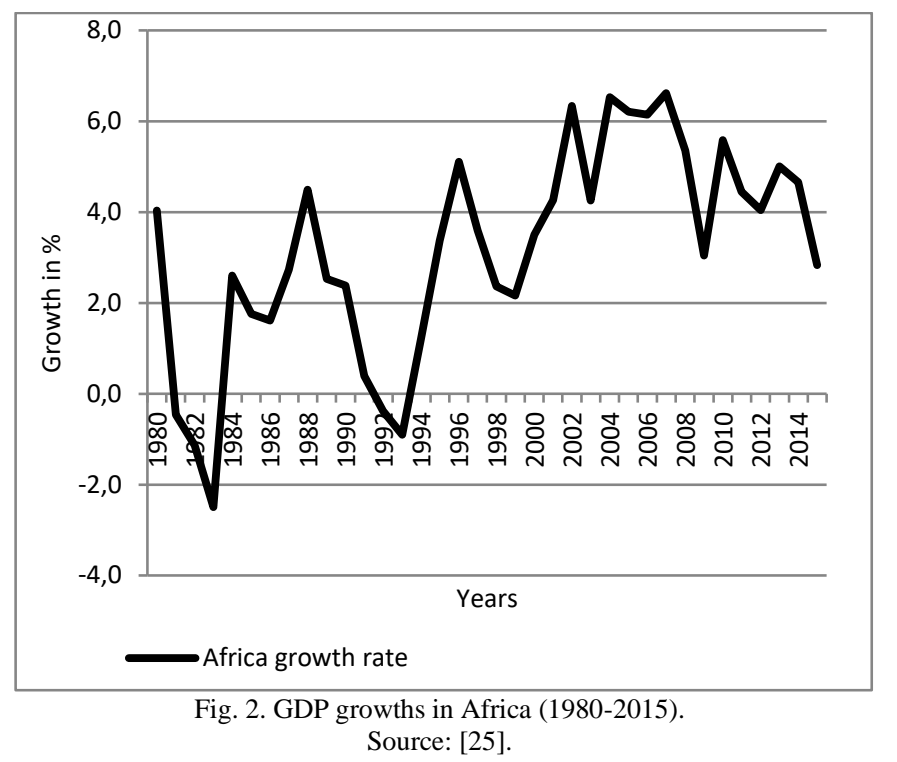

TABLE I: AFRICAN GDP GROWTH RATES BY COUNTRY TYPE (2000-2015)

\begin{tabular}{|c|c|c|c|c|c|}
\hline \multirow{2}{*}{\multicolumn{2}{|c|}{$\begin{array}{c}\text { Slow growth } \\
\text { Economies } \\
\text { Less than } 4 \% / \text { year }\end{array}$}} & \multirow{2}{*}{\multicolumn{2}{|c|}{$\begin{array}{l}\text { Sustainable growth } \\
\text { economies } \\
\text { more than } 4 \% / \text { year }\end{array}$}} & \multicolumn{2}{|c|}{ Oil exporters } \\
\hline & & & & $\mathrm{OPEC} / \mathrm{Nc}$ & PEC \\
\hline Car & -0.01 & Senegal & 4.03 & Libya & -1.00 \\
\hline Zimbabwe & 0.02 & Benin & 4.26 & Gabon & 2.43 \\
\hline Eretria & 1.28 & Botswana & 4.27 & Algeria & 3.66 \\
\hline Ivory Coast & 2.62 & Mauritius & 4.37 & Egypt & 4.21 \\
\hline Comoros & 2.66 & Malawi & 4.39 & Cameroon & 4.29 \\
\hline Madagascar & 2.85 & Morocco & 4.47 & Mauritania & 4.56 \\
\hline Togo & 2.86 & Kenya & 4.48 & Congo & 4.66 \\
\hline Lesotho & 2.89 & Liberia & 4.67 & Niger & 4.73 \\
\hline $\begin{array}{c}\text { Guinea } \\
\text { Bissau }\end{array}$ & 2.98 & Mali & 4.77 & Sudan & 5.31 \\
\hline $\begin{array}{l}\text { South } \\
\text { Africa }\end{array}$ & 3.12 & Namibia & 4.96 & Nigeria & 7.54 \\
\hline Swaziland & 3.31 & Sao Tome & 4.97 & Angola & 7.58 \\
\hline Gambia & 3.49 & Cape Verde & 5.04 & Chad & 8.32 \\
\hline Tunisia & 3.50 & Burkina Faso & 5.52 & $\begin{array}{c}\text { Equatorial } \\
\text { Guinea }\end{array}$ & 12.82 \\
\hline Guinea & 3.53 & Ghana & 6.26 & & \\
\hline Lesotho & 3.89 & Zambia & 6.52 & & \\
\hline Mali & 4.77 & Tanzania & 6.60 & & \\
\hline $\begin{array}{l}\text { South } \\
\text { Africa }\end{array}$ & 3.12 & Uganda & 6.73 & & \\
\hline & & Mozambique & 7.43 & & \\
\hline & & Rwanda & 8.03 & & \\
\hline & & Ethiopia & 9.04 & & \\
\hline
\end{tabular}

Source: [25].

The robust economic growth was largely driven by major government funded projects in the real sector, increased flow of foreign direct investments and economic reforms which emphasised on the revival of the agriculture, tourism as well as the transport sector. The increase in commodity prices together with the improvement in the corporate governance of these countries complimented the improvement in economic performance [27]. However, dismal economic performance occurred in Central African Republic (CAR), Zimbabwe and Eretria which recorded less than $2 \%$ growth with $0,02 \%$ and negative 0,1 in Zimbabwe and Eretria, respectively amid political and social tensions which were taking toll on economic activities [27]. For instance, the 
Eritrean economy was not immune from the security threats in the Horn of Africa and droughts.

The economic situation was worsened by the global financial crises however the discovery of mineral in 2011 slightly improved the economic prospects. The low commodity prices over the same period slowed down economic growth patterns to less than $4 \%$. Poor governance structure, regulatory framework combined with hyperinflation hugely contributed to the demise of the growth prospects of the Zimbabwean economy. These factors drove away both foreign and domestic investors. The situation was further worsened by the poor institutional framework which had high levels of corruption and misappropriation of funds thus failing to channel funds to economic sectors. Resultantly, the economy was plunged in huge foreign debt and was slammed with sanctions which deprived the country from foreign aid. However, the birth of the unity government and adoption of the multi-currency regime in 2010 brought some marginal benefits to the economy though the weak institutional framework remains an impediment [25].

\section{LITERATURE REVIEW}

\section{A. Theoretical Literature}

The Keynesian theory explains the relationship between oil price and economic growth in the short run and long run using the Aggregate Supply (AS) and Aggregate Demand (AD).

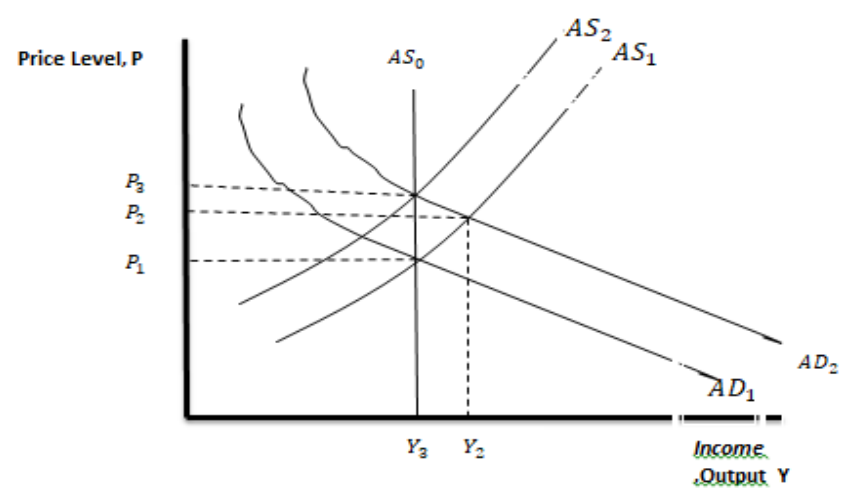

Fig. 3. Keynesian theory. Source: Pindyck and Rubinfield [28].

The short run and the long run periods are represented by the upward AS curve and the vertical AS curve, respectively. The changes in the AD will bring changes in both output and prices in the short run while the effect is only on prices in the long run [29]. The short and long run effect on output following an oil price change is represented in the Fig. 3 above.

Fig. 3 above explains the dynamics of oil price change on economic growth both in the short term and long term. In the short run, the economy will be having spare capacity to produce more output hence the Aggregate Supply (AS) will be upward sloping as in $\mathrm{AS}_{1}$ and $\mathrm{AS}_{2}$. However, the long run scenario will be having a vertical AS curve signifying full employment of resources. An increase in oil price in an oil producing economy will result in an increase in the level of household income and non-oil sector investments thus increasing the level of Aggregate demand which will be represented by a rightward shift of Aggregate Demand (AD) from $\mathrm{AD}_{1}$ to $\mathrm{AD}_{2}$. This will result in a simultaneous increase in the price level from $P_{1}$ to $P_{2}$ and output from $Y_{3}$ to $Y_{2}$. The magnitude of increase of increase in output and price level in the short run will depends on the angle of the AS curve. Steeper slope of an AS curve will result in minimum effect on output than the price.

Contrastingly, the long run effect of oil price increase will be reduced due to intertemporal consumption habits and capital adjustments costs. The short run increase in price level will make households to reduce their consumption gradually to the long run position and increase in investment expenses have a bearing on the cost of production. Resultantly, output will decline as indicated by the leftward shift of the AS curve from $\mathrm{AS}_{1}$ to $\mathrm{AS}_{2}$ in Fig. 3. According to the Keynesian theory, rising oil prices will result in an increase in output in the short run while the long run output remains constant at $\mathrm{Y}_{3}$.

\section{B. Empirical Literature}

Various scholars have explored the impact of oil price changes (increase/decrease) on economic activity of both oil exporting and importing countries [30]-[34]. These studies report mixed results from different economies. While some studies conclude that oil price have a crucial direct and indirect impact on economic growth, other studies find an insignificant relationship. A wide array of literature found positive and significant of oil price on economic growth on oil exporting economies as economies use increasing oil revenues to boost both oil and non-oil sectors of the economy (see [20], [35]-[37]). Kellan [38] finds a significant decline in GDP after an oil price shock for United States, Italy, and France, but an insignificant effect is reported for the economy of Japan. Similarly, Ciscar et al. [39] analyses the potential effects of oil price on European Union (EU) using the General Equilibrium model and finds a negative relationship between oil price and economic activity. Similar results were found by Anoruo and Elike [40] based on oil importing African countries; and Keikha et al. [41] based on oil dependent countries.

On the contrary, some scholars have the view that oil price changes have lost their significance on economic activity of various economies. For instance, Jimenez-Rodriguez and Sanchez [32] report that there is a non- linear impact of oil price shocks on GDP growth of both oil importing and exporting countries. Similar results were found by Hareth [30] who examined the impact of oil price shocks on the SriLankan economy [34], [32] and [31] while analyzing the effect of oil price in the U.S economy. These results might have been influenced by the technological advancement. For instance, the development electrical production processes which reduced the use of oil which were occurring in these economies and the prevalence of other inputs of production reduced the significance of oil in production.

Numerous studies reiterate that oil prices may be an important factor in affecting economic growth [24], [42][44]. These studies presented both theoretical and empirical evidence on estimated impact of oil price on economic growth through various transmission mechanisms. Gounder and Bartleet [45] used a multivariate framework to assess the short run impact of oil price on economic growth and found out that oil price has an immediate effect on inflation and a trivial effect on exchange rate but insignificant in the labour 
market. Furthermore, the general impulse response and error decomposition reaffirm the direct link between net oil price and economic growth of New Zealand.

Another strand of literature focused on country specific developing economies [46]-[48]. Baghirov [46] investigated the direct and indirect effect of oil price shocks on economic growth of Lithuania using VAR model. The results showed that oil price shocks were significant to economic growth of Lithuania and oil price growth was negatively correlated to economic growth. When granger causality tests were carried, it was discovered that oil price measure granger causes real GDP growth rate of Lithuania and its trade partner Russia. Oil price shocks lead to prolonged reduction of GDP in Philippine [49]. On the contrary, oil price fluctuations proved to be insignificant in the Singaporean economy [50]. Similar results were found by Wakeford [51] and [52] on their studies in South Africa and Tunisia, respectively. Canta [53] carried out a study on the Ghanaian economy and realized that oil price pose both a short run and long run negative effect on economic growth. In a similiar study Naveed [54] measured the effect of oil price change on economic output of Ghana and found a positive relationship and a negative relationship in the short run and long run, respectively. The results of country specific case studies might have been influenced by insufficient data points. Meaningful results are realized if there are sufficient data points to meet degrees of freedom hence the justification of focusing on cross country analysis.

A large proportion of literature focused on developed countries [39]-[41], [55], [56]. Killan [56] discovered that United States, Italy, and France experienced a significant decline in GDP after the oil price decrease but the effect of such a shock was insignificant to economy of Japan. Mehdi [55] revealed that oil price granger causes economic growth for Sweden, United Kingdom (UK), Denmark, Norway, and Finland. Similar results were found by Ciscar et al. [39] who analyses the potential effects of oil price on European Union (EU) using the General Equilibrium model. JimenezRodriguez and Sanchez [33] have revealed that crude oil price increase tends to have adverse effect on industrial output and economic growth for the United States (US) economy, but the common consensus was that the relationship has been unstable. This was confirmed by Blanchard and Gali [57] who made the comparison of the effect of oil price to output with those of the 1970s. Similarly, Bretschger [58] found increase in oil price to be insignificant to economic growth in the study of thirty-seven developed countries. The results of the developed economies have been justified on the grounds that their safeguarding structures and signaling indicators which are taken seriously before oil shock. Sahbi [59] carried out his research for U.S and other developed countries and realized that sound monetary stance of the reserve banks of those economies played a major role in supporting the respective economies against the effects of oil price shocks. A similar study by Cavallo and $\mathrm{Wu}$ [60.] revealed that oil price is negatively related to economic growth for US economy for a period from 1984 to 2006.

Other studies have focused on a group of developing countries [41], [61]-[63]. Hakan et al. [66] revealed that oil price is statistically significant to economic growth of Algeria Tunisia, Jordan, Kuwait, and Iran. Similar results were found by Elike and Anoruo [64], on their study of the effect of oil price on oil importing African countries and Keikha et al. [41] on their study of the effect of oil price on selected oil dependent countries.

Several studies based their studies on both oil importing and exporting countries (see, for example, [65], [66], [69]. These studies compared the effect of oil price on economic activity on these two sets of economies. Ghalayin [70] found out that oil price increase did not cause an increase in growth for oil exporters. However, Berument et al. [20] used a VAR technique on a group of net oil exporters, net oil importers in the Middle East economies and realized a positive and significant relationship of oil price and economic growth on oil exporting economies but the effect on economic performance of oil importing economies have been insignificant. Similarly, Mahmud [67] revealed a weak positive relationship of oil price on economic activity of oil importers than oil exporters.

The quality of institutions and economic growth literature has been widely researched and most studies reveal that economies with good quality institutions experience high economic growth. The empirical findings on institutional quality and economic growth nexus were supported by studies which revealed slow economic performance in resource abundant economies [71], [72]. Such resource curse scenario was further confirmed by Ding and Field [73] who found out a negative relationship between resource abundance and economic growth leading to the Dutch disease phenomenon. However, the Dutch disease was non- existent in a study carried out by Spataforca and Warner [74] on a group of oil exporting economies for a 20 year period stretching from 1960.

A wide array of literature on institutional quality and economic growth focuses on the resource abundance countries. Aunty [71] revealed that poor economic performance in resource rich countries was mainly driven by poor political and economic institutions. Similar results were confirmed by Sarch and Warner [72] in their study which was carried out from 1971 to 1989 on 95 resource abundant developing countries. On the same note, a comparison was made by Anderson et al. [75] between poor resource fastest growing economies with resource rich poor economies. The results indicated that the distortions between these groups of economies explain the differences in their level of growth and no other determinants of economic growth economies. Removal of such distortions in resources economies of New Zealand and Austria accelerated their growth during the period of study [75]. Similarly, the level of institutional quality as measured by property rights explains the difference in economic growth between resource rich economies of US, Britain and Germany to other resource rich economies which included Nigeria. Well defined property rights, good policy framework was among reasons of such differences [76]. Similarly, Gylfason [77] realized that only four countries namely Botswana, Indonesia Malaysia, and Thailand in a group of sixty-five resource abundant countries managed to surpass $25 \%$ economic growth due to the investments which were made to solidify their institutional quality.

The resource curse theory attracted a lot of attention in the study of institutional economics. A study by Papyrakis and Gerlach [78] revealed a negative relationship between natural resource and economic growth in a two factor variable 
analysis. However, such a relationship tends to be positive if other control measures which include institutional quality are added in the analysis. Acemoglu and Robinson [79] concurred with the argument of Papyrakis and Gerlach [78] in a study carried out to analyse the relationship between institutional quality and economic growth. The results confirmed the importance of good institutional framework on economic growth. Furthermore, Robert's [80] study in the Niger delta supported the resource curse premise where his study concluded that greed, bad governance, and poor resource management were key contributory factors to poor development in an oil rich economy of Nigeria. The same results were confirmed by Akinwale [81] who realized that the volatility of oil prices was insignificant to economic growth but corruption, poor technology, weak institutions and the Dutch disease and the existence of corruption and weak institutions will hamper any effort to address the economy. On the same line, Ross [82] confirmed the resource curse in Venezuela where he revealed that natural resource curse is mainly determined by weak democracy and institutional framework which will result into violence thus undermining the contribution of such resources to economic growth. Moreover, the abundance of oil in Venezuela has created greediness, corruption, conflicts, and dictatorship further damaging the economy [83]. Evidence from Godwin and Chuka [83] further supports the resource curse hypothesis where the abundance of natural resources crowds out human capital which adversely affects economic growth via the linkage of negatively affecting institutional quality. A given minimum level of institutional quality will make natural resources to have a positive impact on economic growth [84].

\section{Methodology}

The panel Auto-regressive distributed lag (PARDL) specified below follows the works of Peseran et al. [85]:

$\operatorname{ARDL}(p, q, q, q \ldots, q)$

where $\mathrm{p}$ is the lag for the dependent variable and $\mathrm{q}$ is the lag for the explanatory variables which constitute the main variable and control variables [86].

The PARDL model is specified as follows:

$Y_{i t}=\sum_{j=1}^{p} \partial_{i j} Y_{i, t-j}+\sum_{j=0}^{q} \beta_{i j}^{\prime} X_{i t}+\varphi_{i}+e_{i t}$

where

$Y_{i t}$ is the dependent variable;

$\left(X^{\prime}{ }_{i t}\right)^{\prime}$ is the $k \times 1$ vector that are allowed to be purely $I(0)$ and $I(1)$ or cointergrated;

$\partial_{i j}$ is the coefficient of the lagged dependent variable;

$\beta^{\prime}{ }_{i j}$ is the $k \times 1$ coefficient vectors;

$\varphi_{i}$ is the unit-specific fixed effect;

$i$ represents countries used in the research from $1,2,3, \ldots \ldots \ldots . . . \mathrm{N}$;

$t$ represent the time period covered by the research from $1,2, \ldots \ldots . \mathrm{T}$;

$p$ and $q$ are optimal lag orders;

$e_{i t}$ is the error term which represents other factors which are affect economic growth which are excluded in this study.
The ARDL (p,q,q,q) is re-paremeterised to error correction model which will be specified as follows:

$\Delta Y_{i t}=\theta_{i}\left[Y_{i, t-1}-\mathrm{U}_{i}{ }_{i} X_{i t}\right]+\sum_{j=1}^{p-1} \vartheta_{i j} \Delta Y_{i, t-j}+$

$\sum_{j=0}^{q-1} \beta^{\prime}{ }_{i j} \Delta X_{i, t-j}+\varphi_{i}+e_{i t}$

where

$\theta_{i}=-\left(1-\partial_{i j}\right)$ group specific speed of adjustment coefficient expected that $\theta_{i}<0$;

$\mathrm{U}^{\prime}{ }_{i}$ is the vector of long-run relationship;

$Y_{i, t-1}-\mathrm{U}^{\prime}{ }_{i} X_{i t}$ is the error correction term (ECT);

$\vartheta_{i j}, \beta^{\prime}{ }_{i j}$ are short-run dynamic coefficients.

The ECT represents the long-run information of the model hence Error Correction Model (ECM) is of importance in running Panel ARDL. Furthermore, differencing will lead to a loss of a lag thus resulting in a lag of $p-1$ in the ECM.

The growth function will be as follows:

rgdppc, $=f(o p$, instqlty, op -

institutional quality, inf, di, ge, un, er)

Applying the panel ARDL to the above function will result in the following model:
$\ln r g d p p c_{i t}=\alpha_{i j} \sum_{j=1}^{p} \ln r g d p p c_{i, t-j}+\sum_{j=0}^{q} \beta_{i j} \operatorname{lnop}_{t-j}+$ $\sum_{j=0}^{q} \omega_{i, j}$ lninstqlty $_{i, t-j}+\sum_{j=0}^{q} \varphi_{i, j}$ lnop - instqlty ln,$t-j+$ $\sum_{j=0}^{q} \tau_{i, j} \ln i r_{i, t-j}+$
$\sum_{j=0}^{q} \rho_{i, j} \ln d i_{i, t-j}+\sum_{j=0}^{q} \vartheta_{i, j} \ln u e_{i, t-j}+$ $\sum_{j=0}^{q} \pi_{i, j} \ln g e_{i, t-j}+e_{i t}$

The above equation is Re-parameterized into the equation below so that it captures the long-term relationship, and the short-term adjustment equation will give:

$$
\begin{aligned}
& \Delta \operatorname{lnrgdppc} c_{i t}=\sum_{j=1}^{p-1} \Delta \alpha_{i j} \operatorname{lnrgdpp}_{i, t-j}+\sum_{j=0}^{q-1} \Delta \beta_{i j} \operatorname{lnop}_{t-j}+ \\
& \sum_{j=0}^{q} \Delta \omega_{i, j} \text { lninstqulty }_{i, t-j}+\sum_{j=0}^{q} \varphi_{i, j} \text { lnop - instqlty } \text { int }-j+ \\
& \sum_{j=0}^{q-1} \Delta \tau_{i, j}+\sum_{j=0}^{q-1} \Delta \rho_{i, j} \ln d i_{i, t-j}+\sum_{j=0}^{q-1} \Delta \vartheta_{i, j} \ln u e_{i, t-j}+ \\
& \sum_{j=0}^{q-1} \Delta \pi_{i, j} \ln g e_{i, t-j}+\sum_{j=0}^{q-1} \Delta \sigma_{i, j} \ln e r_{i, t-j}+\gamma_{i} E C T_{i, t-j}+\varphi_{i}+ \\
& e_{i t}
\end{aligned}
$$

where

$\operatorname{lnrgdppc} c_{i t}$ is real gross domestic product per capita adjusted to constant USD 2010;

$\operatorname{lnop}_{t}$ represents international oil price in USD;

lninstqlty $_{i, t}$ is institutional quality index constructed using the PCA method;

ln $i r_{i t}$ represents inflation rate measured by consumer price index (CPI);

$\ln d i_{i t}$ refers to domestic investment measured by a percentage of gross fixed capital formation to real GDP;

$\ln u n_{i t}$ refers to unemployment measured as percentage of labour force $\ln g e_{i t}$ refers to government expenditure as percentage of real GDP;

ln $e r_{i t}$ is the exchange rate of local currency for each country against the USD;

$\gamma_{i}$ is the short-run adjustment to the long-term relationship and is an important indicator of the existence of the long-run relationship; 
$E C T_{i t}$ is the error correction term which directly estimates the speed at which a dependent variable returns to equilibrium after a change in other variables.

$$
\begin{aligned}
& E C T_{i, t-j}=\operatorname{lnrgdpp}_{i t}-\mathrm{U}_{i}\left[\alpha_{i j} \sum_{j=1}^{p} \operatorname{lng} g d p p c_{i, t-j}+\right. \\
& \sum_{j=0}^{q} \beta_{i j} \operatorname{lnop}_{t-j}+\sum_{j=0}^{q} \omega_{i, j} \operatorname{lninstqlty} y_{i, t-j}+ \\
& \sum_{j=0}^{q} \varphi_{i, j} \operatorname{lnop}-\text { instqlty }_{i, t-j}+\sum_{j=0}^{q} \tau_{i, j} \ln \mathrm{ir}_{i, t-j}+ \\
& \sum_{j=0}^{q} \rho_{i, j} \ln d i_{i, t-j}+\sum_{j=0}^{q} \vartheta_{i, j} \ln u e_{i, t-j}+ \\
& \left.\sum_{j=0}^{q} \pi_{i, j} \ln g e_{i, t-j}+\sum_{j=0}^{q} \sigma_{i, j} \ln e r_{i, t-j}\right]
\end{aligned}
$$

\section{ESTIMATION RESULTS AND INTERPRETATIONS}

\section{A. Correlation}

Table II shows a correlation plot of the 8 variables with the correlation values inside the boxes. The plot shows highest value of 0.61 between RGDP/capita and unemployment. Thus, since we have most values below 0.8 , we rule out the

\begin{tabular}{|c|c|c|c|c|c|c|c|c|}
\hline & Inf_rate & Ex_rate & Oil_price & Dom_invest & Gvt_expenditure & RGD/capita & Unemply & $\begin{array}{c}\text { Institutional } \\
\text { quality }\end{array}$ \\
\hline Inf_rate & 1 & -0.22 & -0.77 & -0.09 & -0.06 & -0.04 & -0.02 & -0.12 \\
\hline Ex_rate & -0.22 & 1 & 0.19 & 0.03 & -0.21 & -0.33 & -0.47 & -0.08 \\
\hline Oil_price & -0.07 & 0.19 & 1 & 0.25 & 0.03 & 0.13 & -0.09 & -0.3 \\
\hline Dom_invest & -0.09 & 0.03 & 0.25 & 1 & 0.25 & 0.29 & 0.24 & 0.14 \\
\hline Gvt_expenditure & -0.06 & -0.21 & 0.29 & 0.28 & 1 & 0.28 & 0.37 & 0.14 \\
\hline RGD/capita & -0.04 & -0.33 & 0.13 & 0.29 & 0.28 & 1 & 0.61 & 0.27 \\
\hline Unemply & -0.02 & -0.47 & -0.09 & 0.24 & 0.37 & 0.61 & 1 & 0.22 \\
\hline Institutional quality & -0.12 & -008 & -0.3 & 0.14 & 0.14 & 0.27 & 0.22 & 1 \\
\hline
\end{tabular}
problem of multi collinearity. The same exploration was done within the oil groupings and regions and although high correlations were noticed on some variables.

TABLE II: CORRELATION MATRIX

Source: Author's computation 2020.

\section{B. Unit Root Test}

The results for the unit roots are represented in Appendix A unit root tests for the African economies. It shows that RGDP/capita which is the dependent variable has a unit root for the global sample. Appendix A indicates those variables which become stationary after first difference with I(1) while stationary series are represented by I(0). Oil price, institutional quality and unemployment series also shows the existence of a unit root across the different samples' groups. The rest of the other variables are stationary at level.

\section{Optimal Root Lag}

Based on the most common lags in Appendix I, the following root lags were chosen using the AIC criteria for each of the variables.

\begin{tabular}{cc}
\multicolumn{2}{c}{ TABLE III: OPTIMAL RoOT TEST } \\
\hline \hline Variable & Optimal root Lag \\
& Con \\
\hline RGdp/capita & $\mathrm{I}(1)$ \\
Oil_price & $\mathrm{I}(1)$ \\
Instqlty & $\mathrm{I}(1)$ \\
Infl_rate & $\mathrm{I}(0)$ \\
Unmply & $\mathrm{I}(1)$ \\
Gvt_exp & $\mathrm{I}(0)$ \\
Dom_invst & $\mathrm{I}(1)$ \\
Ex_rate & $\mathrm{I}(0)$ \\
\hline Source: Author's computation 2020.
\end{tabular}

\section{Bound Test Cointegration Test}

Since the series are mixed with both I (0) and I (1) the bound test as suggested by Pesaran and Shin [86] is going to be used. The cointegration is going to be performed at the level form of the variables or log transformation. In this research, log variables were used. Note that the hypothesis for the test is as follows: $\mathbf{H}_{\mathbf{0}}$ : No Cointegration equation vs $\mathbf{H}_{\mathbf{1}}$ : There is cointegration equation. Considering the optimal lags represented in Table III, where oil price, institutional quality and unemployment appears as first lag and first difference with others being first differenced with a lagged dependent variable RGDP/capita these can be incorporated in the ARDL model in R. The Pesaran, Shin and Smith (PSS) bound test is more appropriate since our model involves I (1) and I (0) series. Table IV indicates the bound test results which confirm the existence of some long run relationship among the I(1) series with RGDP/capita. This is justified by the F statistic value $=5.613$ is greater than I (1) critical value of 4.01 at $5 \%$ level. Thus, we can conclude that oil price, institutional quality, inflation rate and unemployment have a cointegrating relationship with the dependent variable RGDP/capita. The t-statistic of 4.525 falling below the $5 \%$ critical value for I (1) also qualifies that our model specification and the unique, long-run relationship exists among the four variables.

TABLE IV: PSS BOUND TEST

\begin{tabular}{ccc}
\hline \hline & F-test & \\
\hline & $\mathrm{I}(0)$ & $\mathrm{I}(1)$ \\
\hline & 2.45 & 3.52 \\
10\% critical values & 2.86 & 4.01 \\
$1 \%$ critical value & 3.74 & 5.06 \\
F-statistic=5.613 & & \\
\hline & T-test & $\mathrm{I}(1)$ \\
\hline & $\mathrm{I}(0)$ & -3.66 \\
\hline 10\% critical value & -2.57 & -3.99 \\
$5 \%$ critical value & -2.86 & -4.6 \\
$1 \%$ critical value & -3.43 & \\
t- statistic= -4.525 & &
\end{tabular}

Source: Author's computation 2020.

\section{E. Hausman Test}

The Hausman test is used to select the model between MG and PMG by testing whether there is a significant difference between MG and PMG. The Hausman chi square test results presented in Table $\mathrm{V}$ below shows that the difference between MG and PMG is not significant as indicated by a chi square value of 0.52 which is positive and greater than zero. The probability is found to be greater than 0.05 thus implying that the PMG is more efficient than MG. The results are consistent with the theoretical underpinnings that the PMG assumes 
country specific heterogeneity emanating from the differences in institutional frameworks. Furthermore, the sample is expected to be homogeneous with respect to economic growth and oil price changes since the economies considered share the same level of development [88]. Moreover, the time period for this study is inconsistent with the MG model since it may lack the degrees of freedom. Also, the PMG compared to MG offers more efficient results under the assumption of long-run heterogeneity [89]. Resultantly, the PMG estimation technique is employed in this study.

TABLE V: HAUSMAN TEST

\begin{tabular}{ccccc}
\hline \hline Variable & $(\mathrm{b})$ & $(\mathrm{B})$ & $\begin{array}{c}(\mathrm{b}-\mathrm{B}) \\
\text { Difference }\end{array}$ & $\mathrm{SE}$ \\
\hline OP & 0.2317 & 0.0677 & 0.1640 & 0.3131 \\
Institutional & 10718.66 & -0.01234 & 10718.66 & 2714.08 \\
quality & 0.1324 & -0.024 & 0.1564 & 0.2874 \\
Inf_rate & -3.7282 & -0.0013 & -3.7294 & 7.2451 \\
Un_rate & -0.4307 & -0.17074 & -2.5991 & 0.6608 \\
Ge & 1.0755 & 0.4631 & 0.6124 & 3.3732 \\
Di & -0.7902 & 0.1541 & -0.9442 & 1.7954 \\
Exch_rate & 0.52 & & & \\
\hline CHI & & & & \\
Prob>chi ${ }^{2}=$ & 0.9142 & & & \\
\hline
\end{tabular}

Source: Author's computation 2020.

\section{MODEL ESTIMATION}

The coefficient of oil price for the oil exporting economies is consistent with the coefficient of all African economies although the impact is marginal higher. The results are explained in terms of marginal impact on economic growth. After controlling for inflation rate, unemployment, government expenditure, domestic investment and exchange rate, the results show that oil price has a positive and significant impact on economic growth. The impact is much stronger as compared to the regional sample suggesting the stronger influence of oil price change has on exporting economies compared to oil importing economies with Africa. Since higher oil prices translate into higher economic growth, this result confirms the notion that oil exporting economies benefit from oil price increase as they translate to higher revenues which are diversified to non-oil industries for the benefit of such economies. However, decrease in oil price will hurt the economies if funds are not created during periods of oil price hikes.

The results offer support to the second hypothesis of this study. Oil price increase benefits net oil exporters while the effect is detrimental to a group of net oil importers. The results are consistent with the established Keynesian theory which states that an increase in oil price will improve the economy. Empirically, these results are consistent with majority of studies suggesting the increase in price of oil improves economic growths of oil exporting economies [90], Sadhagi [36], Berument et al. [91], Moneasa and Qazi [92] and Adedekun [93]. This proves that oil exporting countries in Africa are still dependent on oil revenues for their growth. On the other hand, these results contradict the results Ghalayin [70] and Mahmud [67]) who found insignificant effect of oil price on economic growth suggesting economic diversification, fiscal consolidation and establishment of funds thus reducing the relevance of oil price on economic growth.
Results in Table VI depict the importance of institutional quality in the oil price nexus. Results indicates that institutional quality in is positive and significant in the short run and lung run however the impact has declined in the long run realizing the importance of improving the quality of institutional for the betterment of African economies as a whole. Good quality institutions manage oils and use them in in diversifying other sectors of the economy. Moreover, fiscal policies and monetary policies are drafted to enhance economic activities in the wake of oil price changes. The results are consistent with the positive theory of new institutional economics which emphasises on improving quality of institution for attainment of economic growth. Similar results were reported by Bouzid [94], Rodrik [95] and Rodriguez and Sanchez [33] who realized the importance of institutional quality on economic growth. Furthermore, Lane and Tomell [96], Eiffert [97] and Mehlum et al. [98] found similar results. However, the magnitude of institutional quality on economic growth found in this study was less compared to the studies highlighted above due to the diversity of African institution within the region for instance corruption, voice and accountability rule of law are still undermined in most African states compared to institutions in other religions which are more advanced and influential in economic prosperity of those regions [25].

Notes $* * * * *, *$ indicate significance of statistics at $1 \%$, $5 \%$ and $10 \%$ level of significance, respectively. The standard errors are in parenthesis. Dependent variable is rgdp constant 2010 .

TABLE VI: REGIONAL MODE

\begin{tabular}{|c|c|}
\hline Variables & Oil exporting \\
\hline \multicolumn{2}{|l|}{ Long run equation } \\
\hline Oil price & $\begin{array}{c}0.544 * * * \\
(0.046)\end{array}$ \\
\hline Institutional quality & $\begin{array}{c}0.042 * * \\
(0.017)\end{array}$ \\
\hline Inflation rate & $\begin{array}{c}-0.052 * * \\
(0.021)\end{array}$ \\
\hline Unemployment rate & $\begin{array}{c}-0.195 * * \\
(0.093)\end{array}$ \\
\hline Government expenditure & $\begin{array}{c}-0.452 \text { *** } \\
(0.112)\end{array}$ \\
\hline Domestic investment & $\begin{array}{l}-0.070 \\
(0.049)\end{array}$ \\
\hline Exchange rate & $\begin{array}{c}0.092 * * * \\
(0.015)\end{array}$ \\
\hline Short run equation & \\
\hline ECT & $\begin{array}{c}-0.108 * * \\
(0.046)\end{array}$ \\
\hline Oil price & $\begin{array}{c}-0.013^{*} \\
(0.05)\end{array}$ \\
\hline Institutional quality & $\begin{array}{l}0.0965 \\
(0.127)\end{array}$ \\
\hline Inflation rate & $\begin{array}{c}0.003 \\
(0.008)\end{array}$ \\
\hline Unemployment rate & $\begin{array}{c}0.002 \\
(0.118)\end{array}$ \\
\hline Government expenditure & $\begin{array}{c}-0.078 * * * \\
(0.022)\end{array}$ \\
\hline Domestic investment & $\begin{array}{c}0.033 \\
(0.022)\end{array}$ \\
\hline Exchange rate & $\begin{array}{c}-0.011 \\
(0.028)\end{array}$ \\
\hline Constant & $\begin{array}{l}1.152^{* * *} \\
(0.504)\end{array}$ \\
\hline Observations & 216 \\
\hline
\end{tabular}

Source: Author's computation 2020. 
Results on unemployment are highly positive and significant in both the short run and long run but the magnitude declines in the long run. This is largely explained by the advanced production methods which are capital intensive and do not call for huge amount of labour force. Moreover, African economies are driven by rents from few resources thus leaving significant number of people unemployed. Similar results were reported by Levine [99] on European countries amid a paradigm shift from labour intensive to capital intensive production methods. The results on domestic investment and inflation follow the theoretical underpinnings. On the other hand, the effect of exchange rate and government expenditure are highly insignificant in both the short run and the long run. Most African economies run controlled exchange rate regimes thus rendering them insignificant to economic growth while fiscal expenditure among African countries is misdirected to political activities at the expense of economic activities. Similar results on effect of government expenditure on economic growth were also reported by Usman et al. [100] and Salih [101] who could not find any significance influence of government expenditure on economic growth on the pretext of political funding and recurrent expenditure.

\section{Diagnostics Tests}

\section{A. Auto Correlation}

In order to ensure quality of the model, auto-correlation is tested in the series through a Breusch-Godfrey test in R using the dynardl.auto-.correlation function in the dynamic package. Table VIII indicates that there are no white noises in the series as the null hypothesis of no correlation is not rejected with a p-value of 0.243 . Normality test in this case is not necessary as alluded by Gules [102].

TABLE VII: AUTOCORRELATION TEST FOR THE ARDL MODEL

\begin{tabular}{ccc}
\hline \hline Test & Test statistic & P-Value \\
\hline Breusch-Godfrey LM & 1.365 & 0.243 \\
Shapiro-Wilk test for & 0.664 & 0 \\
Log-likelihood & 799.053 & AIC $=-1572.107$ \\
\hline Source: Author's computation 2020.
\end{tabular}

Therefore, we conclude that series are free of white noise and note that normality is not an issue as supported by Gules [102]. Thus, a conclusion of no white noises involved is made.

\section{B. Stability Test}

Fig. 4 shows the shock series of the economy via $R G D P /$ capita due to changes in all the significant I (1) variables model. Fig. 4 a, 4 b and $4 \mathrm{c}$ show the shock levels of the $R G D P /$ capita with respect to oil price, unemployment, and institutional quality, respectively. Whilst both oil price and unemployment shock occur at about 10 years, the shock has an immediate effect as it does not last long, there seems to be continuous immediate shock effects on the institutional quality. This shows how sensitive institutions can be to the overall development of an economy. The shock is also of great magnitude as it is always greater than one. Of interest is the fact that the shock due to unemployment has a very sharp rise above 3 sigma values above the mean. Fig. 4

\section{$\mathrm{X}$}

\section{CONCLUSIONS AND POLICY RECOMMENDATIONS}

The paper assessed the influence of oil price changes and institutional quality on economic growth for all African economies. panel Autoregressive distributed lag was used to estimate the effects of oil price and institutional quality on African economies for a period from 1990 to 2016. The paper concluded that oil price changes have a significant positive effect on economic growth of the sample for African economies both in the short run and the long run. This implies that African economies tend to benefit from an oil price increase and loose from an oil price decline. This put weight behind calls for diversification during periods of oil price increases in Africa as a continent. Secondly, Panel results for African economies indicate that institutional quality is positive and significant to economic growth. This suggests that institutions in Africa need to be improved for growth to be realized.

The policy lesson that can be distilled from the findings is that there is need for strengthening the fiscal frameworks so as to establish a stronger foundation of long-term fiscal sustainability through hedging and indexing government bonds to oil prices. This will reduce the exposure of shortterm fluctuations of oil price. Furthermore, economies need to restore the fiscal space by reforming the energy subsidy thus discouraging wasteful energy consumption and generating capacity for programmes that are beneficial to the economy. Furthermore, Economies should adopt stabilization policies which counter the risks associated with changing oil prices by pursuing with accommodative monetary policies. This can be achieved through interest rates adjustment in oil exporting economies. The paper also suggests that policy measures should stress development of institutional infrastructure that is able to redistribute oil rents to viable economic sectors for fostering economic development.

$\mathrm{d}-\mathrm{f}$ is the corresponding CUSUM charts of the RGDP /capita variable when shocks due to oil price, unemployment and institutional quality are affected, respectively. Institutional quality shock seems to be explosive as indicated by Fig. 5 whilst there is stability with the other variables.

\section{CONCLUSIONS AND POLICY RECOMMENDATIONS}

The paper assessed the influence of oil price changes and institutional quality on economic growth for all African economies. panel Autoregressive distributed lag was used to estimate the effects of oil price and institutional quality on African economies for a period from 1990 to 2016. The paper concluded that oil price changes have a significant positive effect on economic growth of the sample for African economies both in the short run and the long run. This implies that African economies tend to benefit from an oil price increase and loose from an oil price decline. This put weight behind calls for diversification during periods of oil price increases in Africa as a continent. Secondly, Panel results for African economies indicate that institutional quality is positive and significant to economic growth. This suggests that institutions in Africa need to be improved for growth to 
be realized.

The policy lesson that can be distilled from the findings is that there is need for strengthening the fiscal frameworks so as to establish a stronger foundation of long-term fiscal sustainability through hedging and indexing government bonds to oil prices. This will reduce the exposure of shortterm fluctuations of oil price. Furthermore, economies need to restore the fiscal space by reforming the energy subsidy thus discouraging wasteful energy consumption and generating capacity for programmes that are beneficial to the

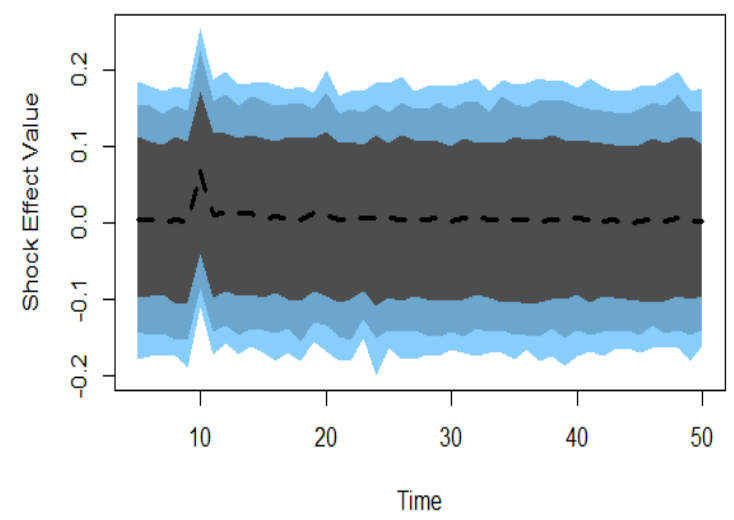

a) oil shock

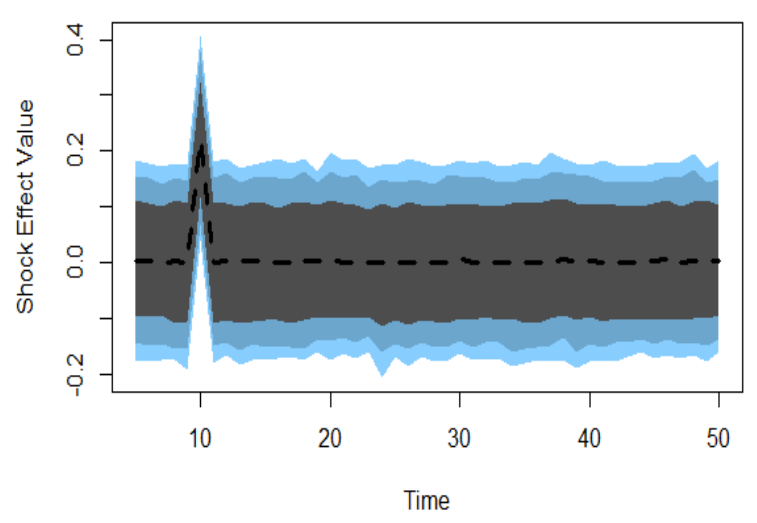

b) Unemployment shock

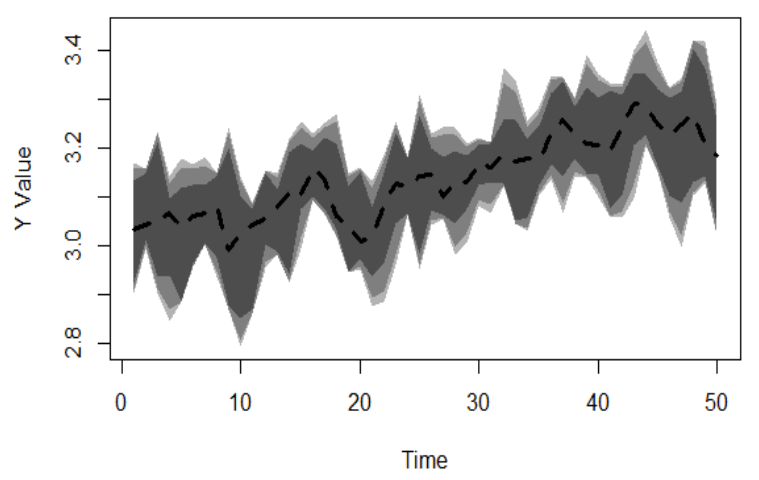

c) institutional quality shock economy. Furthermore, Economies should adopt stabilization policies which counter the risks associated with changing oil prices by pursuing with accommodative monetary policies. This can be achieved through interest rates adjustment in oil exporting economies. The paper also suggests that policy measures should stress development of institutional infrastructure that is able to redistribute oil rents to viable economic sectors for fostering economic development.

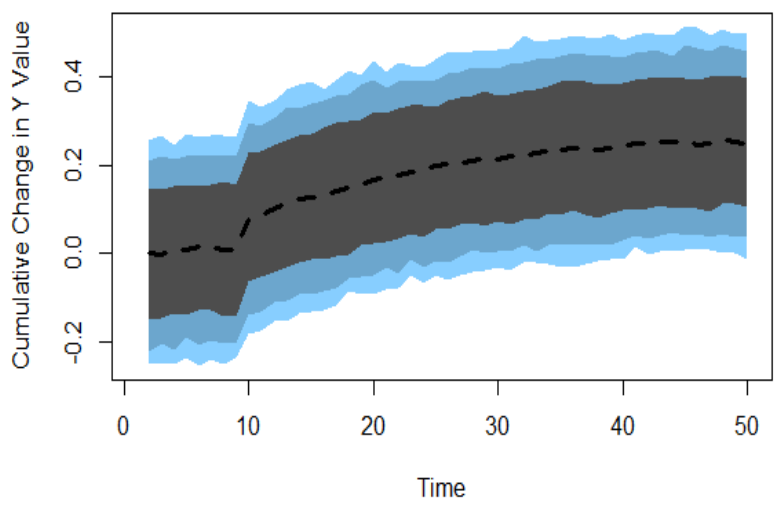

d)CUSUM oil shock

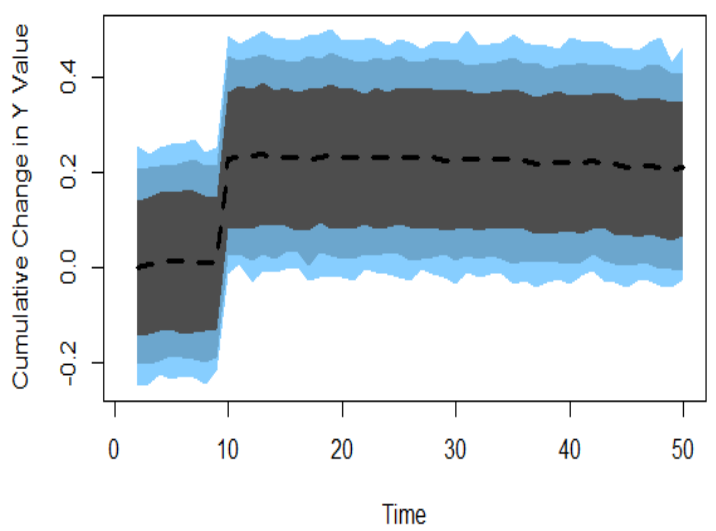

e) CUSUM with Unemployment shock

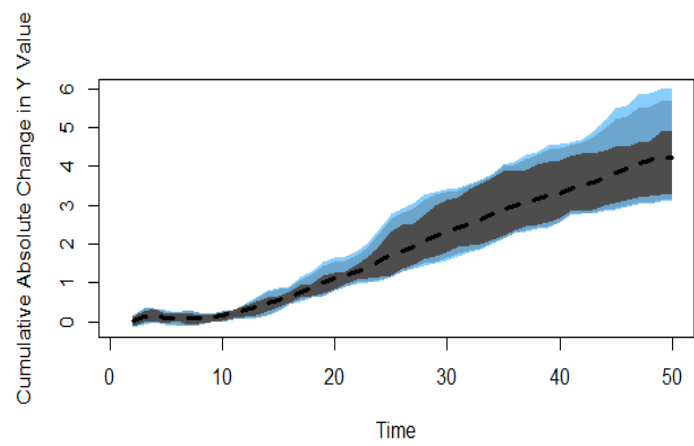

f) CUSUM institutional quality

Fig. 4. SHOCK and CUSUM charts. 


\section{APPENDIX}

\section{A. Appendix A Unit roots}

TABLE VIII: PESARAN RoOT TEST-AUGUMENTED DiCKEy FULLER

\begin{tabular}{|c|c|c|c|c|c|c|c|c|c|c|c|c|}
\hline \multirow[t]{2}{*}{ Variable } & \multicolumn{2}{|c|}{$\begin{array}{l}\text { Global } \\
\text { Sample }\end{array}$} & \multicolumn{2}{|c|}{$\begin{array}{c}\text { Oil } \\
\text { Exporting }\end{array}$} & \multicolumn{2}{|c|}{$\begin{array}{c}\text { Oil } \\
\text { Importing }\end{array}$} & \multirow[t]{2}{*}{ SADC } & \multirow[t]{2}{*}{ EAC } & \multirow[t]{2}{*}{ AMU } & \multirow[t]{2}{*}{ ECCAS } & \multirow[t]{2}{*}{ IGAD } & \multirow[t]{2}{*}{ ECOWAS } \\
\hline & Con & Trend & Con & Trend & Con & Trend & & & & & & \\
\hline RGDPPC & $\mathrm{I}(1)$ & $\mathrm{I}(0)$ & $\mathrm{I}(1)$ & $\mathrm{I}(0)$ & $\mathrm{I}(1)$ & $\mathrm{I}(1)$ & $\mathrm{I}(1)$ & $\mathrm{I}(1)$ & $\mathrm{I}(1)$ & $\mathrm{I}(1)$ & $\mathrm{I}(1)$ & $\mathrm{I}(1)$ \\
\hline Oil_price & $\mathrm{I}(1)$ & $\mathrm{I}(1)$ & $\mathrm{I}(1)$ & $\mathrm{I}(1)$ & $\mathrm{I}(1)$ & $\mathrm{I}(1)$ & $\mathrm{I}(1)$ & $\mathrm{I}(1)$ & $\mathrm{I}(1)$ & $\mathrm{I}(1)$ & $\mathrm{I}(1)$ & $\mathrm{I}(1)$ \\
\hline Instqlty & $\mathrm{I}(0)$ & $\mathrm{I}(1)$ & $\mathrm{I}(0)$ & $\mathrm{I}(1)$ & $\mathrm{I}(1)$ & $\mathrm{I}(1)$ & $\mathrm{I}(1)$ & $\mathrm{I}(1)$ & $\mathrm{I}(1)$ & $\mathrm{I}(1)$ & $\mathrm{I}(1)$ & $\mathrm{I}(1)$ \\
\hline Infl_rate & $\mathrm{I}(0)$ & $\mathrm{I}(0)$ & $\mathrm{I}(0)$ & $\mathrm{I}(0)$ & $\mathrm{I}(0)$ & $\mathrm{I}(0)$ & $\mathrm{I}(0)$ & $\mathrm{I}(0)$ & $\mathrm{I}(1)$ & $\mathrm{I}(0)$ & $\mathrm{I}(1)$ & $\mathrm{I}(0)$ \\
\hline Unmply & $\mathrm{I}(1)$ & $\mathrm{I}(1)$ & $\mathrm{I}(1)$ & $\mathrm{I}(1)$ & $\mathrm{I}(1)$ & $\mathrm{I}(1)$ & $\mathrm{I}(1)$ & $\mathrm{I}(1)$ & $\mathrm{I}(1)$ & $\mathrm{I}(1)$ & $\mathrm{I}(1)$ & $\mathrm{I}(1)$ \\
\hline Gvt_exp & $\mathrm{I}(0)$ & $\mathrm{I}(0)$ & $\mathrm{I}(0)$ & $\mathrm{I}(1)$ & $\mathrm{I}(1)$ & $\mathrm{I}(0)$ & $\mathrm{I}(1)$ & $\mathrm{I}(1)$ & $\mathrm{I}(1)$ & $\mathrm{I}(0)$ & $\mathrm{I}(1)$ & $\mathrm{I}(0)$ \\
\hline Dom_invst & $\mathrm{I}(0)$ & $\mathrm{I}(0)$ & $\mathrm{I}(0)$ & $\mathrm{I}(1)$ & $\mathrm{I}(1)$ & $\mathrm{I}(0)$ & $\mathrm{I}(1)$ & $\mathrm{I}(1)$ & $\mathrm{I}(1)$ & $\mathrm{I}(0)$ & $\mathrm{I}(1)$ & $\mathrm{I}(1)$ \\
\hline Ex_rate & $\mathrm{I}(0)$ & $\mathrm{I}(0)$ & $\mathrm{I}(0)$ & $\mathrm{I}(0)$ & $\mathrm{I}(0)$ & $\mathrm{I}(0)$ & $\mathrm{I}(0)$ & $\mathrm{I}(1)$ & $\mathrm{I}(1)$ & $\mathrm{I}(0)$ & $\mathrm{I}(1)$ & $\mathrm{I}(0)$ \\
\hline D.gdp & $\mathrm{I}(0)$ & - & $\mathrm{I}(0)$ & - & $\mathrm{I}(0)$ & $\mathrm{I}(0)$ & $\mathrm{I}(0)$ & $\mathrm{I}(0)$ & $\mathrm{I}(0)$ & $\mathrm{I}(0)$ & $\mathrm{I}(0)$ & $\mathrm{I}(0)$ \\
\hline d.Oil_price & $\mathrm{I}(0)$ & $\mathrm{I}(0)$ & $\mathrm{I}(0)$ & $\mathrm{I}(0)$ & $\mathrm{I}(0)$ & $\mathrm{I}(0)$ & $\mathrm{I}(0)$ & $\mathrm{I}(0)$ & $\mathrm{I}(0)$ & $\mathrm{I}(0)$ & $\mathrm{I}(0)$ & $\mathrm{I}(0)$ \\
\hline d.instqlty & $\mathrm{I}(0)$ & $\mathrm{I}(0)$ & - & $\mathrm{I}(0)$ & $\mathrm{I}(0)$ & $\mathrm{I}(0)$ & $\mathrm{I}(0)$ & $\mathrm{I}(0)$ & $\mathrm{I}(0)$ & $\mathrm{I}(0)$ & $\mathrm{I}(0)$ & $\mathrm{I}(0)$ \\
\hline d.Infl_rate & - & - & - & - & - & - & - & - & $\mathrm{I}(0)$ & - & $\mathrm{I}(0)$ & - \\
\hline d. unmply & $\mathrm{I}(0)$ & $\mathrm{I}(0)$ & $\mathrm{I}(0)$ & $\mathrm{I}(0)$ & $\mathrm{I}(0)$ & $\mathrm{I}(0)$ & $\mathrm{I}(0)$ & $\mathrm{I}(0)$ & $\mathrm{I}(0)$ & $\mathrm{I}(0)$ & $\mathrm{I}(0)$ & $\mathrm{I}(0)$ \\
\hline d.Gvt_exp & - & - & - & & $\mathrm{I}(0)$ & - & $\mathrm{I}(0)$ & $\mathrm{I}(0)$ & $\mathrm{I}(0)$ & - & $\mathrm{I}(0)$ & - \\
\hline D.Dom_invst & - & - & - & $\mathrm{I}(0)$ & $\mathrm{I}(0)$ & - & $\mathrm{I}(0)$ & $\mathrm{I}(0)$ & $\mathrm{I}(0)$ & - & $\mathrm{I}(0)$ & $\mathrm{I}(0)$ \\
\hline d.Ex_rate & - & - & - & - & - & - & - & $\mathrm{I}(0)$ & $\mathrm{I}(0)$ & - & $\mathrm{I}(0)$ & - \\
\hline
\end{tabular}

TABLE IX: UNIT ROOT PP TEST

\begin{tabular}{|c|c|c|c|c|c|c|c|c|c|c|c|c|}
\hline \multirow[t]{2}{*}{ Variable } & \multicolumn{2}{|c|}{ Global Sample } & \multicolumn{2}{|c|}{ Oil Exporting } & \multicolumn{2}{|c|}{ Oil Importing } & \multirow[t]{2}{*}{ SADC } & \multirow[t]{2}{*}{ EAC } & \multirow[t]{2}{*}{ AMU } & \multirow[t]{2}{*}{ ECCAS } & \multirow[t]{2}{*}{ IGAD } & \multirow[t]{2}{*}{ ECOWAS } \\
\hline & $\mathrm{C}$ & $\mathrm{T}$ & $\mathrm{C}$ & $\mathrm{T}$ & $\mathrm{C}$ & $\mathrm{T}$ & & & & & & \\
\hline RGDPPC & $\mathrm{I}(1)$ & $\mathrm{I}(0)$ & $\mathrm{I}(1)$ & $\mathrm{I}(0)$ & $\mathrm{I}(1)$ & $\mathrm{I}(1)$ & $\mathrm{I}(1)$ & $\mathrm{I}(1)$ & $\mathrm{I}(1)$ & $\mathrm{I}(1)$ & $\mathrm{I}(1)$ & $\mathrm{I}(1)$ \\
\hline Oil_price & $\mathrm{I}(1)$ & $\mathrm{I}(1)$ & $\mathrm{I}(1)$ & $\mathrm{I}(1)$ & $\mathrm{I}(1)$ & $\mathrm{I}(1)$ & $\mathrm{I}(1)$ & $\mathrm{I}(1)$ & $\mathrm{I}(1)$ & $\mathrm{I}(1)$ & $\mathrm{I}(1)$ & $\mathrm{I}(1)$ \\
\hline Instqlty & $\mathrm{I}(0)$ & $\mathrm{I}(1)$ & $\mathrm{I}(0)$ & $\mathrm{I}(1)$ & $\mathrm{I}(1)$ & $\mathrm{I}(1)$ & $\mathrm{I}(1)$ & $\mathrm{I}(1)$ & $\mathrm{I}(1)$ & $\mathrm{I}(1)$ & $\mathrm{I}(1)$ & $\mathrm{I}(1)$ \\
\hline Infl_rate & $\mathrm{I}(0)$ & $\mathrm{I}(0)$ & $\mathrm{I}(0)$ & $\mathrm{I}(0)$ & $\mathrm{I}(0)$ & $\mathrm{I}(0)$ & $\mathrm{I}(0)$ & $\mathrm{I}(0)$ & $\mathrm{I}(1)$ & $\mathrm{I}(0)$ & $\mathrm{I}(1)$ & $\mathrm{I}(0)$ \\
\hline Unmply & $\mathrm{I}(1)$ & $\mathrm{I}(1)$ & $\mathrm{I}(1)$ & $\mathrm{I}(1)$ & $\mathrm{I}(1)$ & $\mathrm{I}(1)$ & $\mathrm{I}(1)$ & $\mathrm{I}(1)$ & $\mathrm{I}(1)$ & $\mathrm{I}(1)$ & $\mathrm{I}(1)$ & $\mathrm{I}(1)$ \\
\hline Gvt_exp & $\mathrm{I}(0)$ & $\mathrm{I}(0)$ & $\mathrm{I}(0)$ & $\mathrm{I}(1)$ & $\mathrm{I}(1)$ & $\mathrm{I}(0)$ & $\mathrm{I}(1)$ & $\mathrm{I}(1)$ & $\mathrm{I}(1)$ & $\mathrm{I}(0)$ & $\mathrm{I}(1)$ & $\mathrm{I}(0)$ \\
\hline Dom_invst & $\mathrm{I}(0)$ & $\mathrm{I}(0)$ & $\mathrm{I}(0)$ & $\mathrm{I}(1)$ & $\mathrm{I}(1)$ & $\mathrm{I}(0)$ & $\mathrm{I}(1)$ & $\mathrm{I}(1)$ & $\mathrm{I}(1)$ & $\mathrm{I}(0)$ & $\mathrm{I}(1)$ & $\mathrm{I}(1)$ \\
\hline Ex_rate & $\mathrm{I}(0)$ & $\mathrm{I}(0)$ & $\mathrm{I}(0)$ & $\mathrm{I}(0)$ & $\mathrm{I}(0)$ & $\mathrm{I}(0)$ & $\mathrm{I}(0)$ & $\mathrm{I}(1)$ & $\mathrm{I}(1)$ & $\mathrm{I}(0)$ & $\mathrm{I}(1)$ & $\mathrm{I}(0)$ \\
\hline D.gdp & $\mathrm{I}(0)$ & - & $\mathrm{I}(0)$ & - & $\mathrm{I}(0)$ & $\mathrm{I}(0)$ & $\mathrm{I}(0)$ & $\mathrm{I}(0)$ & $\mathrm{I}(0)$ & $\mathrm{I}(0)$ & $\mathrm{I}(0)$ & $\mathrm{I}(0)$ \\
\hline d.Oil_price & $\mathrm{I}(0)$ & $\mathrm{I}(0)$ & $\mathrm{I}(0)$ & $\mathrm{I}(0)$ & $\mathrm{I}(0)$ & $\mathrm{I}(0)$ & $\mathrm{I}(0)$ & $\mathrm{I}(0)$ & $\mathrm{I}(0)$ & $\mathrm{I}(0)$ & $\mathrm{I}(0)$ & $\mathrm{I}(0)$ \\
\hline d.instqlty & $\mathrm{I}(0)$ & $\mathrm{I}(0)$ & - & $\mathrm{I}(0)$ & $\mathrm{I}(0)$ & $\mathrm{I}(0)$ & $\mathrm{I}(0)$ & $\mathrm{I}(0)$ & $\mathrm{I}(0)$ & $\mathrm{I}(0)$ & $\mathrm{I}(0)$ & $\mathrm{I}(0)$ \\
\hline d.Infl_rate & - & - & - & - & - & - & - & - & $\mathrm{I}(0)$ & - & $\mathrm{I}(0)$ & - \\
\hline d. unmply & $\mathrm{I}(0)$ & $\mathrm{I}(0)$ & $\mathrm{I}(0)$ & $\mathrm{I}(0)$ & $\mathrm{I}(0)$ & $\mathrm{I}(0)$ & $\mathrm{I}(0)$ & $\mathrm{I}(0)$ & $\mathrm{I}(0)$ & $\mathrm{I}(0)$ & $\mathrm{I}(0)$ & $\mathrm{I}(0)$ \\
\hline d.Gvt_exp & - & - & - & & $\mathrm{I}(0)$ & - & $\mathrm{I}(0)$ & $\mathrm{I}(0)$ & $\mathrm{I}(0)$ & - & $\mathrm{I}(0)$ & - \\
\hline D.Dom_invst & - & - & - & $\mathrm{I}(0)$ & $\mathrm{I}(0)$ & - & $\mathrm{I}(0)$ & $\mathrm{I}(0)$ & $\mathrm{I}(0)$ & - & $\mathrm{I}(0)$ & $\mathrm{I}(0)$ \\
\hline d.Ex_rate & - & - & - & - & - & - & - & $\mathrm{I}(0)$ & $\mathrm{I}(0)$ & - & $\mathrm{I}(0)$ & - \\
\hline
\end{tabular}

Source: Author's computation 2020.

\section{REFERENCES}

[1] International Energy Agency. (2016). IEA energy statistics 2016 Available at (2016) http://www.iea.org/statistics/.

[2] OPEC. (2016). Annual Statistical Bulletin.

[3] International Energy Agency. (2012). Germany. Oil and Gas security, emergency response of IEA countries. 1-13.

[4] Ezeh, A. and Lu, J. (2019). Transforming the institutional landscape in Sub-Saharan Africa: Considerations for leveraging Africa's research capacity to achieve socioeconomic Development. Washington DC 20036.

[5] Yildirim, A. and Gokalp, M.F. (2016). Turkey institutions and economic performance: a review on the developing countries. Procedia Economics and Finance. 38, 347-359.

[6] Owasanoye, B. (2019). Nigeria major contributor to Africa's $\$ 90$ billion illicit financial outflow. 2019 Africa Union (AU) anticorruption day in Lagos.

[7] Epaphra, M. and Kombe, A.H. (2018). Institutions and economic growth in Africa: evidence from panel estimation. Institute of Accountancy Arusha, Tanzania, February, 2018.

[8] Mishkin, F.S. and Schmiddt-Hebbel, K. (2007). Monetary policy under inflation targeting: an introduction. Santiago: Central Bank of Chile.
[9] International Energy Agency. (2020). World Energy outlook 2020 Iea.org/reports/world outlook.

[10] OPEC. (2012b). Monthly Oil Market Report for December 2012.

[11] Global financial report (2020). Bank regulation and supervision a decade after global financial crisis. Washington DC. World Bank.

[12] NYEMX. (2020). WTI crude oil futures and options.www.cmegroup.com.

[13] International monetary fund. (2015). Boom, burst, or prosperity? Managing Sub-Saharan Africa's natural resource wealth. IMF, Washington D.C.

[14] World Bank. (2012). World development indicators. The World Bank, Washington D.C.

[15] AFDB (2012). African development report.

[16] World Bank. (2017). The World Bank annual report. Washington DC: World Bank.

[17] OPEC 2017

[18] OPEC, 2012 World Oil Outlook.

[19] Organization for Economic Cooperation and Development, (2014). OECD Economic Outlook 76, Paris: OECD.

[20] Berument, H., Ceylan, N.B. and Dogan, N. (2010). The Impact of Oil Price Shocks on the economic Growth of Selected Countries. The Energy Journal, 31(1), 149-176. 
[21] International monetary fund. (2014). The impact of high oil prices on the global economy. Research and development, IMF, Washington D.C.

[22] International monetary fund. (2012). Boom, burst, or prosperity? Managing Sub-Saharan Africa's natural resource wealth. IMF Washington D.C.

[23] Duarte, M. and Restuccia, D. (2010). The role of the structural transformation in aggregate productivity. The Quarterly Journal of Economics, MIT Press, 125(1),129-173, February.

[24] Hamilton, J., D. (2009). Causes and Consequences of the Oil Shock of 2007-08. NBER Working Paper No. 15002.

[25] World Bank. (2016). World development report 2016. 91877. Washington DC: World Bank.

[26] Organization of the petroleum exporting countries (OPEC). (2015). Member countries Available: http: // www.opec.org/opec_web/en/about_us/25.htm.

[27] World Bank, (2015). Global economic prospect. The global economy in transition. Washington, DC: World Bank.

[28] Pindyck, R., S. (1994). Volatility and commodity price dynamics. Journal of Futures markets.

[29] Dornbusch, R., Fischer, S. and Kearney. C. 1996. Macroeconomics. The Mc-Graw-Hill Companies, Inc., Sydney.

[30] Harreth, A. (2012). The Role of Oil Prices and the Real Exchange Rate in Russia's Economy-A Cointegration Approach. Journal of Comparative Economics, 32(2), 315-327.

[31] Bartlett W., Cuǐkoviǎ N., Jurlin K., Nojkoviǎ A., Popovski V. (2009) Institutional quality and growth in EU neighbourhood countries. WP5/11 Search Working Paper.

[32] Rajhi, R. A., Seol, Y., \& Yoon, K. H. (2005). Relative energy price and investment by European firms. Energy Economics, 33(5), 721-731.

[33] Jiménez-Rodríguez, R. and Sánchez, M. (2004). Oil price shocks and real gross domestic product growth empirical evidence for some OECD countries. Working Paper Series no. 362.

[34] Sachs, J. and Warner, M. (1995). Natural Resource Abundance and Economic Growth. National Bureau of Economic Research Working Paper 5398.

[35] Adedokun, A., J. (2012). Oil Export and Economic Growth: Descriptive Analysis and Empirical Evidence from Nigeria. Pakistan Journal of Social Sciences, Vol. 9(1), 46-58.

[36] Monesa, L. and Qazi, T. (2013). Effects of oil price shocks on economic growth of oil exporting countries. A case of six OPEC countries Business and economic review. Instiute of Management Science. Peshower Parkistan, Vol 5(1) 65-87.

[37] Sadhagi, A. (2017). Oil price and economic growth in oil expoerting economies. Does the size of government matter. IMF Working Paper.

[38] Kilian, L. (2008b). A Comparison of the Effects of Exogenous Oil Supply Shocks on Output and Inflation in the G7 Countries. Journal of the European Economic Association, 6(1), 78-121.

[39] Ciscar, J., C., Russ, P., Parousos, L. and Stroblos, N. (2004). Vulnerability of the EU economy to oil shocks: A general equilibrium analysis with the GEM-E3 Model. Institute for Prospective Technological Studies.

[40] Anorou, E. and Elike, U. (2009). An empirical investigation into the impact of high oil prices on economic growth of oil-importing African countries. International Journal of Economic Perspectives, 3(2), 121129.

[41] Keikha, A., Keikha, A.and Mehrara, M. (2012). Institutional quality, economic growth and fluctuations of oil prices in oil dependen countries: A panel cointegration approach. Modern economy, 3, 218222.

[42] Mork, K., A. (1994): Business Cycles and the Oil Market. Working Paper 1994/2, the Norwegian School of Management.

[43] Hoover, K., D. and Perez, S., J. (1994). Post hoc ergo propter once more: An evaluation of 'Does monetary policy matter?' in the spirit of James Tobin. Journal of Monetary Economics, 34, 47-73.

[44] Lee, K. and Ni, S. (2002). On the dynamic effects of oil price shocks: A study using industry level data. Journal of Monetary Economics, 49, $823-852$

[45] Gounder, R. and Bartleet, M. (2012). Oil prices shocks and economic growth: Evidence for New Zealand, 1989-2006. Department of applied and international economics, Massey University, Palmerston North.

[46] Baghirov, A. (2014). Direct and indirect effects of oil price shocks on economic growth: Case of Lithuania. ISM University of management and economics.

[47] Raguindin, C. E.and Reyes, R., G. (2005). The effects of oil price shocks on the Philippine economy: a VAR approach. Working Paper, University of the Philippines School of Economics.

[48] Anashasy, E.D. (2006). Evidence on the role of oil prices in Venezuela's economic performance: 1950-2001. Working paper. George Washington University.
[49] Fayyad, A. (2011). Volatility spillover effect of emerging markets and economic growth versus oil price volatility: the case of the gulf cooperation council countries. $\mathrm{PhD}$ thesis.

[50] Chang, Y. and Wong, J., F. (2003). Oil price fluctuations and Singapore economy. Energy Policy, 31, 1151-1165.

[51] Wakeford, J. (2003). The impact of oil price shocks on the South African macro economy: History and prospects. Working Paper No. 06/111. July 2006. Development Policy Research Unit, University of Cape Town.

[52] Bouzide, A. (2014). The Relationship of Oil Prices and Economic Growth in Tunisia: A Vector Error Correction Model Analysis. The Romanian Economic Journal, 3-43.

[53] Canta, W (2014). Crude Oil Price and Economic Growth: The Case of Ghana. Paper presented at the Centre for Study of Africa Economies Conference, Economic Development in Africa. St Catherine's College, University of Oxford, and 23-25 March 2014.

[54] Naveed, I.S. (2010). Measuring the impact of changing oil prices and other macroeconomic variables on GDP in the context of Pakistan's economy. International Research Journal of Finance and Economics, 52,569-599

[55] Mehdi, B. (2013). The relationship between Market Size, Inflation and Energy. Atlantic Review of Economics 2

[56] Kilian, L. (2008b). A Comparison of the Effects of Exogenous Oil Supply Shocks on Output and Inflation in the G7 Countries. Journal of the European Economic Association, 6(1), 78-121.

[57] Blanchad, O. and Gali, J. (2008). The macro-economic effects of oil price shock: why are the 2000s so different from the 1970s? Forthcoming in: Gali and Gerthler (Eds). University of Chicago Press, Chicago.

[58] Bretschger, L. and Zurich, E., T., H. (2013). Energy prices, growth, and the channels in between: Theory and evidence. CER-ETH Centre of Economic Research at ETH Zurich.

[59] Sahib, F. (2013). Impact of oil price increases on U.S. economic growth: Causality analysis and study of the weakening effects in relationship. International Journal of Energy Economics and Policy 2(3), 2012, pp.108-122 ISSN: 2146-4553

[60] Cavallo, M. and Wu, T. (2006). Measuring Oil-Price Shocks Using Market-Based Information. Federal Reserve Bank of San Francisco Working Paper Series, WP 2006-28.

[61] Alom, F. (2012). Economic effects of oil and food price shocks in Asia and Pacific countries: an application of the SVAR model. Paper provided by New Zealand Agricultural and Resource Economics Society in its series 2011 Conference, August 25-26, 2011, Nelson, New Zealand No. 115346.

[62] Fayyad, A. (2011). Volatility spillover effect of emerging markets and economic growth versus oil price volatility: the case of the gulf cooperation council countries. PhD thesis.

[63] Nilsson, A. and Sundqvist, A. (2010). Oil price effects on economic growth: A comparison between the BRIC countries and the Western World (G7). Bachelor Thesis in Economics.

[64] Elike, U.and Anoruo, E. (2009). An empirical investigation into the impact of high oil prices on economic growth of oil-importing African countries. International Journal of Economic Perspectives, 3(2), 121129.

[65] Lau, E. and Jayarama, T.K. Oil Price and Economic Growth in Small Pacific Island Countries. Modern Economy, 2011, 2, 153-162.

[66] Hakan, K. and Nildag, B. C. (2014). The impact of oil price shocks on the economic growth of selected MENA Countries. Atlim University.

[67] Mahmud, S. (2013). Oil Demand, Oil Prices, Economic Growth and the Resource Curse: An Empirical Analysis. Thesis submitted for the degree of Doctor of Philosophy.

[68] Dimitrios, A. and Daniel, D., V. (2012). The effects of oil price on macroeconomic variables in oil exporting and oil importing countries. International Journal of Energy, Environment, and Economics 21(4).

[69] Zeinab, K.and Amirreza, K. (2013). The impact of oil price fluctuations on macro-economic variables of demanding and supplying countries. International Monthly Refereed Journal of Research In Management \& Technology, 2 ISSN - 2320-0073.

[70] Ghalayin, L. (2011). The Interaction between Oil Price and Economic Growth.Article in review of Middle East economics and finance.

[71] Auty, R., M. (2007). Rent recycling theory, the resource curse, and development policy. Developing Alternatives. 11(1), 7-13.

[72] Sachs, J. and Warner, M. (1995). Natural Resource Abundance and Economic Growth. National Bureau of Economic Research Working Paper 5398.

[73] Ding, N. and Field, B.C. (2005). Natural resource abundance and economic growth. Land Economics, 81(4). 496-500.

[74] Spatafora, N. and Warner, A. (2001). Macroeconomic and sectoral effects of term of trade shocks: The experience of oil exporting 
developing countries. Paper presented at European Economic Association Meeting, Brussels.

[75] Anderson, S., P., Jacob, K., G. and Charles, A., H. (1998). Rent seeking with bounded rationality: an analysis of the all-pay auction. Journal of politics and economy, 106, 828-853.

[76] Stijns, J.P.C. (2000). National Resource Abundance and Economic Growth Revisited. Department of Economics, University of California at Berkeley.

[77] Gylfason, T. (2001). Natural Resources, Education, and Economic Development. European Economic Review, 45:847-854.

[78] Gerlach, R. and Papyrakis, E. (2004). The resource curse hypothesis and its transmission channels. Journal of Comparative Economics, 32: 181-93.

[79] Acemoglu, D., Johnson, S., and Robinson, J.A. (2002). An African success: Botswana, in D. Rodriquez (Ed.), Analytic development narratives. Princeton: Princeton University Press.

[80] Robert, O.D. (2011). The political economy of resource curse and the Niger delta crisis in Nigeria: matters arising. Afro Asian Journal of social sciences $5,45-67$.

[81] Akinwale, Y.O. (2012). Empirical analysis of resource curse in Nigeria. International Journal of Economics Management and Science, 2(13): 330-378.

[82] Ross, M.L. (2013). The oil curse: How petroleum wealth shapes the development of nations. Princeton University Press.

[83] Godwin, E.A. and Chuka, C. (2014). Natural resources, human capital, and economic development in Nigeria: Tracing the linkages. Journal of Economics and Economic Sustainable Development. 5, 35-52.

[84] Sarmidi, T., Law, S.H. and Jafari, Y. (2014). Resource Curse: New Evidence on the Role of Institutions. International Economic Journal, 28, 191-206.

[85] Pesaran, M.H. Shin, Y. and Smith, R.P. (1999). Pooled mean group estimation of dynamic heterogeneous panels. Journal of the American Statistical Association, 94 (446)

[86] Loayza, N.V., Ranci re, R., (2006). Financial development, financial fragility, and growth. Journal of Money, Credit and Banking, 38(4), 1051-1076

[87] Pesaran, M.H. Shin, Y. and Smith, R.P. (2001). Bounds testing approaches to the analysis of level relationships. Journal Of Applied Econometrics, 16, 289-326.

[88] Samargandi, N. (2014). Easays on financial development and economic growth. A Thesis Submitted for Degree of Doctor of Philosopy.Brunel University.

[89] Eberhardt, M. and Teal, F. (2011). Econometrics for grumblers: A new look at the literature on cross country growth empirics. Journal of Economic Surveys, 25(1), 109-155.

[90] Hakan, K. and Nildag, B. C. (2014). The impact of oil price shocks on the economic growth of selected MENA Countries. Atlim University.

[91] Berument, H., Ceylan, N. B. and Dogan, N. (2013). The Impact of Oil Price Shocks on the economic Growth of Selected Countries. The Energy Journal, 31(1), 149-176.

[92] Monesa, L. and Qazi, T. (2013). Effects of oil price shocks on economic growth of oil exporting countries. A case of six OPEC countries Business and economic review. Instiute of Management Science. Peshower Parkistan, Vol. 5(1) 65-87.

[93] Adedokun, A., J. (2012). Oil Export and Economic Growth: Descriptive Analysis and Empirical Evidence from Nigeria. Pakistan Journal of Social Sciences, Vol. 9(1), 46-58.

[94] Bouzide, A. (2012). The Relationship of Oil Prices and Economic Growth in Tunisia: A Vector Error Correction Model Analysis. The Romanian Economic Journal, 3-43.

[95] Rodrik, D. (2001). Institutions, integration and geography: In search of deep determinants of growth. Retrieved December 15, 2016.

[96] Lane, P. and Tornell, A. (1999). The voracity effect. American economic Review, 89 (1), 22-46.

[97] Eifert, B., Gelb, A. and Tallroth, N., B. (2002). The Political Economy of Fiscal Policy and Economic Management in Oil Exporting Countries, World Bank Policy Research Working Paper 2899, October.

[98] Mehlum, H., Moene, K. and Torvik, R. (2006). Institutions and the Resource Curse, Economic Journal, 116, 508, 1-20.

[99] Levine, L. (2013). Economic growth and the unemployment rate. Congressional Research Service, 1-7.

[100]Usman, A., Mobolaji, H. I., Kilishi, A. A., Yaru, M. A., \& Yakubu, T. A. (2011). Public Expenditure and Economic Growth in Nigeria. Asian Economic and Financial Review, 1(3), 104-113.

[101] Salih, M. A. R. (2012). The Relationship between Economic Growth and Government Expenditure: Evidence from Sudan. International Business Research, 5(8), 40-46. http://dx.doi.org/10.5539/ibr.v5n8p40.

[102]Gules, R. (2013). Design and implementation of an electronic load: Applied power electronics conference and exposition 1166-1171.
[103] Essandoh-Yeddu. J. and Yalamova, R. (2015). Current drop in oil prices: impact on Africa. International Association for Energy Economics (IAEE) Energy Forum 4th Quarter (2015), 37-40 View Record in Scopus.

[104]Fields, G., S. (2011). Labor market analysis for developing. Labour economics, 18 (1), 16-22.

[105]Papyrakis, E. and Gerlagh, R. (2004). The resource curse hypothesis and its transimission channels. Journal of Comparative Economics 32 181-93.

[106]The Economist, (2016). The Economist Nigeria Petrol Subsidies: A Fuel and Your Money (May 19th edition) (2016) https://www.economist.com/news/middle-east-and-africa. 